ficação para a visão unificada da cultura ou dos problemas particulares de desenvolvimento histórico não fica, de modo nenhum, suficientemente esclarecida.

Quanto ao problema inicial, o de investigar os fatôres responsáveis pelo "progressismo" da comunidade, as conclusões nos parecem insatisfatórias. O autor afirma que "a investigação compreendida neste estudo sugere que propor uma questão dêste tipo é levantar um falso problema. Não há, afinal de contas, nenhuma razão lógica para pensar que uma série simples de processos possa 'explicar' por que uma cidade e não outra parece progressista. Alguns fatôres podem ser selecionados e postos em destaque, mas os mesmos fatôres podem estar presentes em outro lugar, sem que os mesmos acontecimentos se repitam. Isso deriva do fato inevitável de que cada comunidade é um acontecimento único; é produto de uma história local peculiar que, por sua vez, é feita de minúsculas seqüências de vida e de ação, impossíveis de se reproduzirem completamente através de análise histórica" (págs. xi-xii).

Parcce-nos que a colocação inicial do problema é perfeitamente legítima. Mas o que se pode pretender através da investigação antropológica não é certamente reconstituição completa de uma realidade histórica particular, mas, ao contrário, no nível de abstração que nos permite tratar de estruturas, chegar-se, através da análise, a determinar fatôres gerais, que seriam fundamentais para um determinado tipo de resultado.

O autor, no capítulo final, apresenta determinantes gerais do processo particular de mudança social em Muquiyauyo, a saber, intensificação dos contactos com a sociedade mais ampla (construção da estrada de ferro para Lima, estabelecimento de minas em distritos próximos), o crescimento da população, a divisão da propriedade, a transformação do sistema de estratificação social, a unificação da comunidade em ações políticas de interêsse geral. Entretanto, não há sequer uma tentativa de aprofundar a análise em têrmos da relação entre êsses elementos. Embora reconhecendo que todos os elementos apontados são importantes, não se pode concluir que todos tenham a mesma importância explicativa. O autor não põe a descoberto a relação dinâmica entre os diferentes elementos, nem sua importância relativa, embora o próprio trabalho acentue a importância crucial da destruição do sistema de castas e concomitante unificação e autonomia da ação política.

Conquanto o autor não tenha podido realizar uma análise comparativa das comunidades da região, o texto sugere que, por êsse meio, se poderia chegar a discernir um fator diferencial no desenvolvimento de Muquiyauyo, responsável, em grande parte, pelo seu "progressismo" particular. Entretanto, não há uma tentativa de exploração mais aprofundada neste sentido. Em sua maior parte, o tratamento do assunto fica em nível descritivo. Aborda-se o problema da estratificação na primeira parte do livro, sem que, no entanto, se expliquem satisfatòriamente as bases do sistema ou se apresentem quer os fatos econômicos que o sustêm, quer os padrões culturais que the definem a dinâmica.

Em resumo, embora o trabalho levante e formule problemas de grande interêsse para o estudo da mudança cultural, a análise do material não explora integralmente as possibilidades implícitas na própria apresentação dos dados.

\title{
Eunice Ribeiro Durham
}

ROGER BASTIDE: Sens et Usages du Terme Structure dans les Sciences Humaines et Sociales. 165 págs. Mouton \& Co. Haia, 1962.

Derivado do verbo latino struere, construir, o têrmo estrutura encerra, na linguagem corrente, três significados básicos que concorrem para defini-lo: a) um conjunto; 
b) as p̧artes dêsse conjunto; c) as relações das partes entre si. As ciências se apom deraram dêste conceito, utilizado primeiramente em, biologia e em lingüística, de onde por analogia passou para a sociologia, na qual tem sido empregado de diversas maneiras, mas sempre com aquêles três significados básicos. Os estudos sociológicos tornaram cada vez mais patente a estreita associação dos elementos de um conjunto social e sua interdependência; de tal maneira que uma das primeiras tarefas dos estudiosos é averiguar a posição do elemento estudado dentro do contexto a que pertence e suas relações tanto com os outros elementos quanto com o todo. O esquema de posições e relações a que se chega tem sido em geral denominado estrutura.

Todavia, malgrado a unanimidade quanto a esta definição geral, persistem sérias divergências com relação às orientações principais que devem nortear o emprêgo do têrmo. Assim, para tomarmos dois exemplos significativas, há uma distância grande entre a maneira pela qual o utilizam Claude Lévi-Strauss e Georges Gurvitch .

Claude Lévi-Strauss sofreu, em sua concepção, influências da lógica e da matemática, e define a estrutura como "um sistema bem especificado de relações ou de leiø, que descreve o funcionamento do fenômeno representado, por meio de um modêlo". A estrutura é considerada, pois, como "o sistema de relações latente no objeto", de tal modo que objetos muito diferentes podem apresentar os mesmos sistemas de relações. havendo leis de passagem de um modêlo para outro. Um fato econômico, por exemplo, poderia encerrar estrutura semelhante à de um fato estético ou religioso; o importante é descobrir esta unidade interior. A abordagem estruturalista assim compreendida permitirá uma unificação das diferentes Ciências Sociais em seus pontos fundamentais, isto é, pela descoberta dos modelos estruturais básicos comuns a tôdas elas.

Georges Gurvitch concebe a estrutura como parte intrínseca do objeto estudado, ao contrário de Claude Lévi-Strauss, para quem ela é uma "construção informadora" do objeto. Cada sociedade, cada grupo social, cada forma de sociabilidade, tem sua estrutura especial, que é preciso descobrir; necessário também é estudar as estruturas concretamente existentes nos fatos psicológicos, políticos, econômicos, religiosos etc., assim como nos próprios processos sociais, pois mesmo êstes seguem um esquema em seu desenrolar. A estrutura é compreendida, então, como êste esquema concretamente existente nos fenômenos sociais, quaisquer que sejam. A unificação das Ciências Sociais também seria possível, mas com apoio em estruturas concretamente analisadas e comparadas, e não com a construção de uma espécie de modêlo "ideal" hácicn. F, a comparação se restringiria ao interior das grandes divisões dos fenômenos sociais, isto é, forçosamente a estrutura de uma forma de sociabilidade não será comparável à de uma camada social, pois trata-se de fenômenos socialmente heterogêneos.

Embora divergindo na maneira de definir estrutura, ambos os autores e as correntes que mais ou menos os seguem são unânimes em que não há como confundi-la com os aspectos móveis da realidade social; a dinâmica social é algo concebido como à parte da estrutura, para fins da análise sociológica. Mas, concordando neste ponto, separamse ambas quando consideram a dinâmica no quadro dos estudos sociologicos. Claude Lévi-Strauss é radical a êste respeito e divide resolutamente os campos de interêsse: ao sociólogo e ao antropólogo cabe o estudo das estruturas sociais, ao histcriador o da dinâmica social. Georges Gurvitch, por sua vez, faz um esfôrço para associar a dinâmica à sua concepção de estrutura, insistindo em que esta representa um momento de equilíbrio instável e provisório, cuja consideração em caráter estático é inteiramente ilusória; os conjuntos sociais, quaisquer que êles sejam, são estruturados, mas estão em constante estruturação e desestruturação, de modo que devem ser apreendilos, não sòmente no esquema que forma a estrutura, mas sim e muito mais em tòda esta constante movimentação de estruturação e desestruturação. 
Escolhemos dois exemplos para mostrar que estrutura é ainda um conceito em discussão nas Ciências Sociais, que, como os outros, se vai definindo aos poucos por aproximações sucessivas à realidade que visa a circunscrever e exprimir. Este volume mostra-o muito claramente. Consiste numa série de artigos de vários autores que, reunidos em 1959 num Colóquio sôbre o Têrmo Estrutura, em Paris, sôbre êle discutiram e em seguida apresentaram suas contribuições. Foi organizador do volume o Prof. Roger Bastide, que na introdução coloca os diferentes problemas, além de um desenvolvimentof histórico do significado do têrmo. Com razão diz o Prof. Roger Bastide que as Ciências Sociais apresentam ainda hoje vários "vocabulários técnicos", ainda não integrados de maneira a formar um corpo único. O mérito da obra é o de pôr-nos ao corrente de como é concebido o têrmo "estrutura" nesses diversos vocabulários técnicos.

Maria Isaura Pereira de Queiron 